\title{
Postfire Burnt-Wood Management Affects Plant Damage by Ungulate Herbivores
}

\author{
Jorge Castro \\ Departamento de Ecología, Facultad de Ciencias, Universidad de Granada, 18071 Granada, Spain \\ Correspondence should be addressed to Jorge Castro; jorge@ugr.es
}

Received 12 June 2013; Accepted 15 July 2013

Academic Editor: Friedrich Reimoser

Copyright (c) 2013 Jorge Castro. This is an open access article distributed under the Creative Commons Attribution License, which permits unrestricted use, distribution, and reproduction in any medium, provided the original work is properly cited.

I analyze the effect of post-fire burnt wood management on herbivore attack on a woody plant species (Ulex parviflorus). Two experimental plots of ca. 20 hectares were established at two elevations in a burnt area in a Mediterranean mountain (Sierra Nevada, Spain). Three replicates of three treatments differing in post-fire burnt wood management were established per plot: "no intervention" (NI, all trees remained standing), "partial cut plus lopping" (PCL, felling the trees, cutting the main branches, and leaving all the biomass in situ), and "salvage logging" (SL; removal of logs and elimination of woody debris). Risk of herbivory and damage intensity were monitored for two years. The pattern of attack by ungulate herbivores varied among treatments and years. In any case, there was an overall reduction in the risk of herbivory in the PCL treatment, presumably because the highest habitat complexity in this treatment hampered ungulate movement and foraging. As a result, the burnt logs and branches spread over the ground acted as a physical barrier that protected seedlings from herbivores. This protection may be used for the regeneration of shrubs and trees, and it is of interest for the regeneration of burnt sites either naturally or by reforestation.

\section{Introduction}

A current controversial issue among restoration ecologists and forest managers concerns the appropriate management of dead burnt trees after fire. Post-fire salvage logging (i.e., the felling and removal of the burnt tree trunks, often eliminating the remaining woody debris by chipping, mastication, fire, etc.) has historically been routinely and widely practiced by forest administrations around the world [1-4], particularly in the case of burnt conifer forests. However, there is currently an intense debate about the suitability of this approach [58]. A growing number of studies show that salvage logging may increase soil erosion, diminish the regeneration capacity due to seedling bank or resprout destruction, or reduce the biodiversity of plants and animals $[1,3,6,8]$, among other processes. As a result, there are increasing calls for less aggressive post-fire intervention policies, associated with evidence that snags and decaying burnt wood are components of natural systems that promote ecosystem recovery and diversity [4, 5, 9-12].

An important topic to be considered for the post-fire regeneration of woody vegetation is the effect of ungulate herbivores. Movement and foraging behavior of ungulates is conditioned by habitat characteristics at different spatial scales [13-16]. These characteristics may be related to foodselection preferences according to the palatability of the patch, the accessibility to the area, or to the predation risk suffered by ungulates, among other factors [14, 17-21]. Ungulates are, on the other hand, one of the main factors hampering the success of reforestation efforts as well as natural post-fire recovery of the vegetation [22-25]. Thus, it is likely that the post-fire management of the burnt wood will alter the use of the habitat by ungulate herbivores, as it has the potential to alter accessibility or protection against predators, among other factors (e.g., [20, 27, 28]). The degree that salvage logging changes the habitat could be then of great importance for ungulate foraging decisions and thus determine their impact in the recovering, post-fire plant community. However, little information is available on the effect of salvage logging versus other post-fire management alternatives on the damage of vegetation by ungulate herbivores.

In the present study, I analyze the effect that burntwood management exerts on the herbivory undergone by 
a woody plant species recovering in a burnt area. The burnt wood was experimentally managed to create three scenarios that differed in habitat structure. For the target species, I used a legume shrub (Ulex parviflorus Pourr.; Fabaceae), an obligate seeder that regenerates quickly and abundantly after fires in the Mediterranean region [29, 30]. Ulex species also constitute an important component of the diet of domestic livestock and wild ungulates [31, 32], being therefore an appropriate model to test the effect that habitat structure via burnt-wood management exerts on the risk and magnitude of herbivory soon after the fire. I hypothesise that post-fire burnt-wood management will influence the rate of herbivore damage, as the experimental treatments used contrast sharply in habitat characteristics, ranging from a landscape without tree overstory in salvaged areas to a habitat that still has an overstory of branches and logs in the other treatments.

\section{Methods}

2.1. Study Site, Target Species, and Experimental Design. The study site was located in Sierra Nevada National and Natural Park (SE Spain), where in September 2005 the Lanjarón fire burned ca. 1,300 hectares of pine reforestations with trees of 35 to 45 years old, depending on the stand. Two plots were established after the fire at different altitudinal levels. The plots were homogeneous in terms of orientation (SW), slope (ca. 30\%), fire intensity (high intensity), bedrock (mica schist), and pretreatment tree characteristics. Plot 1 (17.7 hectares in size) was located at $1477 \mathrm{~m}$ a.s.l. (ED 50/UTM zone $30 \mathrm{~N}$, position $x, y: 456070,4089811$ ) and plot 2 (of 23.9 hectares) at $1698 \mathrm{~m}$ (position $x, y$ : 455449, 4091728; altitude and position measured at the centroid of the plot). The pine species present in each plot differed according to their ecological requirements along this elevational gradient. The cluster pine (Pinus pinaster) and the black pine ( $P$. nigra) dominated in plot 1 , whereas the black pine dominated in plot 2. Both pine species are native in the region, although they were extensively planted in the area for forestry purposes. The climate of the area is Mediterranean type, with rainfall concentrated in spring and autumn, alternating with hot, dry summers. Mean annual precipitation at the lowest plot was $466 \mathrm{~mm}$ (1988-2008 period; climatic data from a meteorological station beside plot 1 ). The mean annual temperature was $11.9^{\circ} \mathrm{C}$ at $1652 \mathrm{~m}$ a.s.l. (State Meteorological Agency, period 1994-2008; Ministry of Environment).

Within each plot, three replicates of the following treatments were implemented in a random spatial distribution: (1) "nonintervention" (NI), leaving all of the burnt trees standing; (2) "partial cut plus lopping" (PCL), a treatment where ca. $90 \%$ of burned trees were cut and felled, with the main branches also lopped off, but leaving all the cut biomass in situ on the ground; after treatment application, felled logs and branches covered $45 \%$ of the surface at $0-10 \mathrm{~cm}$ from the ground, $61 \%$ at $11-50 \mathrm{~cm}$, and $9 \%$ at $51-100 \mathrm{~cm}$ [12]; (3) "salvage logging" (SL), where tress were cut and the trunks cleaned of branches with the use of chainsaws. Trunks were manually piled (groups of 10-15) and the woody debris was masticated using a tractor. The Forest Service planned to remove the trunks with a log forwarder in this treatment, but this step was later cancelled due to difficulties in precisely operating machinery within the spatial arrangement of the plots.

The resulting 18 experimental replicates had a size that ranged from 1.2 to 3.5 hectares (average of $2.34 \pm 0.14$; mean $\pm \mathrm{SE}$ ), with no differences among treatments (Kruskal-Wallis test, $P>0.05)$. Salvage logging is the usual post-fire action taken by the local Forest Service, and it was fully implemented throughout the rest of the burnt area where the experimental plots were located. The three treatments differed therefore in the degree of intervention (maximum in SL, intermediate in PCL, and minimum in NI) and in the habitat structure generated (minimum habitat complexity in SL and maximum in PCL; $[12,33])$. All post-fire management treatments were implemented during March to May 2006 (ca. seven months after the 2005 forest fire). The fire was moderate to high in severity, consuming or totally scorching most of the tree crown. Tree density before treatment implementation was $1477 \pm 46$ individuals per hectare for plot 1 and $1064 \pm 67$ for plot 2. Basal tree diameter was $17.7 \pm 0.2 \mathrm{~cm}$ in plot 1 and $18.3 \pm 0.1$ in plot $2[34]$.

Ulexparviflorus is one of the most common seeder species that colonize postburnt areas in the western Mediterranean basin [29, 30]. Like other gorse species (e.g., [32]), $U$. parviflorus is consumed by domestic and wild ungulates in the Mediterranean basin [31]. The species was one of the few woody plants that appeared abundantly in the area after the fire and was present in almost all the replicates of the experiment (see below).

2.2. Seedling Monitoring. In June 2006, I randomly chose and marked 50 seedlings of $U$. parviflorus per replicate and treatment at each of the two plots. One of the replicates of treatment PCL in plot 2 had no seedlings and could not be included in the study. This resulted in 3 treatments $\times$ 3 replicates $\times 50$ seedlings (450 seedlings) for plot 1 and 400 seedlings for plot 2 . Seedling survival, growth, and damage by ungulate herbivores were monitored in October 2006 (thus after the first growing season) and October 2007 (second growing season). Growth parameters included plant height and crown diameter (two perpendicular diameters). Damage by ungulate herbivores (mostly the wild goat Ibex hispanica in the area, and to a lesser extent domestic goats and sheep) was sampled by counting the number of damaged and intact shoots for the first and second growing season. To analyse the herbivore damage, I estimated two indices: (i) risk of herbivory, percentage of $U$. parviflorus plants that underwent at least one event of ungulate damage, and (ii) damage intensity (only for seedlings undergoing herbivory), proportion of the shoots consumed by ungulates. The initial height of the seedlings was $14.6 \pm 0.3 \mathrm{~cm}$ for plot 1 and $13.4 \pm$ $0.3 \mathrm{~cm}$ for plot 2, and ranged between $13.2 \pm 0.4 \mathrm{~cm}$ in NI and $15.2 \pm 0.4 \mathrm{~cm}$ in SL (plots pooled).

The vegetation cover may affect herbivore selection at the patch level $[14,18]$. Thus, I sampled vegetation cover in June 2006, expressed as the number of individuals per square meter. For this, I randomly established 8 transects of $50 \times 2 \mathrm{~m}$ 
TABLE 1: Summary of the two-way ANOVAs for growth parameters measured in Ulex parviflorus plants after two growing seasons (October 2007). Treatments are no intervention, partial cut plus lopping, and salvage logging.

\begin{tabular}{|c|c|c|c|c|}
\hline Variable & Factor & d.f. & $F$-ratio & $P$ \\
\hline \multirow{4}{*}{ Canopy diameter } & Plot $(P)$ & 1 & 71.31 & $<0.0001$ \\
\hline & Treatment $(T)$ & 2 & 5.40 & 0.0047 \\
\hline & $P \times T$ & 2 & 8.86 & 0.0002 \\
\hline & Error & 721 & & \\
\hline \multirow{4}{*}{ Plant height } & Plot $(P)$ & 1 & 48.78 & $<0.0001$ \\
\hline & Treatment $(T)$ & 2 & 2.91 & 0.0552 \\
\hline & $P \times T$ & 2 & 1.02 & 0.3606 \\
\hline & Error & 722 & & \\
\hline
\end{tabular}

size per replicate (placed with their longest dimension along the maximum slope of the terrain) and counted the number of individuals of all the species.

2.3. Data Analyses. Given that one of the replicates of treatment PCL in plot 2 lacked Ulex parviflorus seedlings, I performed the analyses pooling the data of the 2-3 replicates of each treatment per plot. Seedling growth was analysed with mixed two-way ANOVAs, with Plot as a random factor and Treatment as a fixed factor. Trends were similar across years, and only data of the last growing season (after two years) were reported for simplicity. For plant diameter, there was a strong correlation between the two perpendicularly measured diameters $\left(r^{2}=0.68 ; P<0.0001\right)$, and the mean of the two diameters per plant was used as the dependent variable (canopy diameter, hereafter). Risk of herbivory was analysed with a nominal logistic model, considering simultaneously the effect of Plot and Treatment. Damage intensity was analysed with a two-way ANOVA (data arc-sin transformed), considering similarly Plot as a random factor and Treatment as a fixed factor. The relationship between vegetation cover and herbivore attack (risk of herbivory) was explored for year 2006 with a regression analysis using mean cover per replicate as the independent variable. Statistical analyses were performed with JMP 7.0 software (SAS Institute). Throughout the paper, values are mean $\pm 1 \mathrm{SE}$.

\section{Results and Discussion}

Survival after two years was high in all the experimental replicates, with overall values of $88.9 \%$ in NI, 94.5\% in PCL, and $95.7 \%$ in SL (the two plots pooled), supporting that Ulex parviflorus has a high regeneration capacity after fire (e.g., [30]). Among the surviving seedlings, canopy diameter was affected by Plot and Treatment (Table 1). Plants had a higher canopy diameter at the lowest elevation, with values of $40.1 \pm$ $1.2 \mathrm{~cm}$ for NI, $41.1 \pm 1.3 \mathrm{~cm}$ in PCL, and $42.6 \pm 1.2 \mathrm{~cm}$ in SL for plot 1 and $37.5 \pm 1.2,28.6 \pm 1.9$, and $32.8 \pm 0.9$, respectively, for plot 2 (resulting therefore in a significant Plot $\times$ Treatment interaction; Table 1). Plants had similarly higher height at the lowest elevation (Table 1), with values of $43.2 \pm 1.6 \mathrm{~cm}$ for NI, $47.9 \pm 1.4 \mathrm{~cm}$ in PCL, and $44.0 \pm 1.4 \mathrm{~cm}$ in SL for plot 1 and $37.3 \pm 1.4,38.1 \pm 1.4$, and $35.5 \pm 1.1$, respectively, for plot 2 . This was likely due to the altitudinal level, since in plot 2 , at around
$1700 \mathrm{~m}$ a.s.l., U. parviflorus is at its altitudinal upper limit in the area, whereas at $1400 \mathrm{~m}$ it finds appropriate conditions for growth [35]. In any case, differences among treatments were low within plot, and thus it is unlikely that ungulate selection of habitat for foraging could be mediated by plant size. Furthermore, there was no relationship between mean values of plant size per replicate and mean values of damage by herbivores (data not shown).

Vegetation cover (estimated as density of individuals) differed among treatments in the two plots $(F \geq 3.68$, d.f. $=$ $2,69, P \leq 0.0302)$. In plot 1 , the highest value was recorded in NI $\left(3.45 \pm 0.38\right.$ seedlings $\left.\mathrm{m}^{-2}\right)$, followed by PCL $(3.12 \pm 0.31)$ and SL (2.43 \pm 0.28$)$. In plot 2 , the highest was recorded in PCL $(5.70 \pm 0.76)$, followed by NI ( $4.50 \pm 0.37)$ and SL (3.19 \pm 0.33 ; seedlings $\mathrm{m}^{-2}$ in all cases). Nonetheless, the risk of herbivory was not related to the cover of vegetation $(F=0.49$, d.f. $=1$, $15, P=0.4932$ ).

Risk of herbivory differed significantly among plots and treatments for the two years (Table 2). The pattern among treatments changed among plots and years (significant interactions), but PCL was in general the treatment with the lowest values of plants attacked (except plot 1 in year 2006, when NI had lower values; Table 3), with an overall value of $28.5 \%$ for PCL treatment, $38.8 \%$ for NI, and $40.8 \%$ for SL (all plots and years pooled). The level of damage undergone by a target plant may be inversely related to the difficulty or the risk that the herbivore faced in finding the food in a heterogeneous landscape $[14,18,20]$. In this sense, the highest habitat complexity generated by felled logs and branches spread on the ground could hamper the movement of large herbivores in the area, as reported previously in the study site for another ungulate, the wild boar (e.g., [33]). Damage intensity was similar among plots and treatments (Table 2). There were, however, marginally significant differences among treatments in the first year, with the highest value in PCL $(42.9 \pm 3.8 \%)$, followed by SL $(34.8 \pm 2.4)$ and NI $(31.2 \pm 2.3$; the two plots pooled). This result still supports the hypothesis of a reduced ungulate presence in the PCL treatment despite this one having the highest value of damage for the first year: in a situation of more difficulty to find the plants, herbivores likely made more use of the Ulex found in order to compensate for the time invested in foraging [18]. Thus, in short, the results show that post-fire burnt-wood management altered the habitat choice of ungulates and support that burnt logs and 
TABLE 2: Summary of the nominal logistic model for risk of herbivory (proportion of plants that suffered herbivory by ungulates) and twoway ANOVA for damage intensity (proportion of shoots consumed by ungulates in attacked plants) suffered by Ulex parviflorus seedlings in the years 2006 and 2007 (one- and two-year-old plants, resp.). Treatments are no intervention, partial cut plus lopping, and salvage logging.

\begin{tabular}{|c|c|c|c|c|c|c|c|}
\hline & \multirow{2}{*}{ Source } & \multicolumn{3}{|c|}{ Risk of herbivory } & \multicolumn{3}{|c|}{ Damage intensity } \\
\hline & & d.f. & Wald $\chi^{2}$ & $P$ & d.f. & $F$ & $P$ \\
\hline \multirow{4}{*}{ Year 2006} & Plot $(P)$ & 1 & 7.39 & 0.0065 & 1 & 1.42 & 0.3380 \\
\hline & Treatment $(T)$ & 2 & 9.90 & $<0.0071$ & 2 & 11.33 & 0.0811 \\
\hline & $P \times T$ & 2 & 6.86 & 0.0323 & 2 & 0.36 & 0.7008 \\
\hline & Model/Error & 5 & 28.10 & $<0.0001$ & 212 & & \\
\hline \multirow{4}{*}{ Year 2007} & Plot $(P)$ & 1 & 5.86 & 0.0155 & 1 & 1.55 & 0.3383 \\
\hline & Treatment $(T)$ & 2 & 7.67 & 0.0216 & 2 & 0.75 & 0.5710 \\
\hline & $P \times T$ & 2 & 5.50 & 0.0640 & 2 & 6.88 & 0.0012 \\
\hline & Model/Error & 5 & 21.12 & 0.0012 & 264 & & \\
\hline
\end{tabular}

TABLE 3: Mean values for risk of herbivory (proportion of plants that suffered herbivory by ungulates) for years 2006 and 2007 for plants of Ulex parviflorus sampled in the experiment (one- and two-yearold plants, resp.).

\begin{tabular}{llccc}
\hline & & NI & PCL & SL \\
\hline \multirow{2}{*}{ Year 2006 } & Plot 1 & 15.9 & 22.8 & 25.0 \\
& Plot 2 & 31.6 & 19.3 & 41.2 \\
\hline \multirow{2}{*}{ Year 2007 } & Plot 1 & 38.8 & 21.7 & 41.4 \\
& Plot 2 & 46.4 & 38.2 & 39.2 \\
\hline
\end{tabular}

NI: no intervention; PCL: partial cut plus lopping; SL: salvage logging.

branches spread on the ground provided a physical barrier that protected the seedlings against ungulate herbivores.

The Mediterranean gorse U. parviflorus is not a species that requires restoration efforts for its regeneration. Its ability to germinate after heat shock, its resistance to drought, fast growth rate, and early reproduction, virtually guarantee its regeneration after disturbance by fires $[26,30]$. However, the results of this study support the contention that the protection offered by felled logs and branches spread over the ground could benefit either the natural regeneration or reforestation with tree species of interest for forest recovery. Ungulate herbivores are one of the main factors hampering the success of reforestations $[22,36]$ as well as natural post-fire recovery of the vegetation $[23,25]$. It is well known that the physical barrier provided by thorny or spiny shrubs protects the seedlings and saplings of tree species in Mediterranean ecosystems as well as in other ecosystem types (e.g.) $[17,18$, 37-40]). This mechanism of associational resistance (sensu [18]) can also be provided by dead woody structures, which similarly hinder the ungulate access to the saplings protected under their cover. In this sense, Ripple and Larsen [41] reported the protection of aspen by coarse woody debris. Puerta-Piñero et al. [28] and Leverkus et al. [33] reported that felled burnt logs and branches reduced the impact of wild boar predation on sowed acorns, and Relva et al. [20] have shown that logs and branches that collapsed after massive dieback also reduced herbivory by deer. Moreover, the foraging behaviour of ungulate herbivores depends on the context of the target and the protector plant: the lower the palatability of the protector, the higher the chance of protection for a particular target species $[17,18]$. Burnt branches offer low palatability. Thus, it is very likely that their protective role could be expanded to other species more palatable than $U$. parviflorus and to other systems provided that logs, branches, or both are left in situ either naturally or after management.

\section{Acknowledgments}

The author thanks the Direction of the Natural and National Parks of Sierra Nevada and the Consejería de Medio Ambiente of Granada (Junta de Andalucía) for coordinating and implementing the field treatments and for all the technical, material, and personal support they have provided. Ángela Sánchez-Miranda, Ramón Ruiz-Puche, Enrique Pérez Sánchez-Cañete, Mercedes Molina-Morales, Sara MarañónJiménez, Susanna Olsson, and Richard Rassmann provided invaluable field assistance. This study was supported by the Project 10/2005 from the Organismo Autónomo de Parques Nacionales (Spain).

\section{References}

[1] J. D. McIver and L. Starr, "Environmental effects of post-fire logging: literature review and annotated bibliography," Tech. Rep. PNW-GTR-486, USDA, 2000.

[2] M. G. L. van Nieuwstadt, D. Sheil, and K. Kartawinata, "The ecological consequences of logging in the burned forests of East Kalimantan, Indonesia," Conservation Biology, vol. 15, no. 4, pp. 1183-1186, 2001.

[3] D. B. Lindenmayer, P. J. Burton, and J. F. Franklin, Salvage Logging and Its Ecological Consequences, Island Press, Washington, DC, USA, 2008.

[4] J. Castro, C. Puerta-Piñero, A. B. Leverkus, G. Moreno-Rueda, and A. Sánchez-Miranda, "Post-fire salvage logging alters a key plant-animal interaction for forest regeneration," Ecosphere, vol. 3, article 90, 2012.

[5] R. L. Beschta, J. J. Rhodes, J. B. Kauffman et al., "Postfire management on forested public lands of the western United States," Conservation Biology, vol. 18, no. 4, pp. 957-967, 2004.

[6] D. C. Donato, J. B. Fontaine, J. L. Campbell, W. D. Robinson, J. B. Kauffman, and B. E. Law, "Post-wildfire logging hinders 
regeneration and increases fire risk," Science, vol. 311, no. 5759, p. 352, 2006.

[7] D. B. Lindenmayer and R. F. Noss, "Salvage logging, ecosystem processes, and biodiversity conservation," Conservation Biology, vol. 20, no. 4, pp. 949-958, 2006.

[8] J. Castro, G. Moreno-Rueda, and J. Hódar, "Experimental test of postfire management in pine forests: impact of salvage logging versus partial cutting and nonintervention on bird-species assemblages," Conservation Biology, vol. 24, no. 3, pp. 810-819, 2010.

[9] D. B. Lindenmayer, D. R. Foster, J. F. Franklin et al., "Salvage harvesting policies after natural disturbance," Science, vol. 303, no. 5662, p. 1303, 2004.

[10] D. A. DellaSala, G. Nagle, R. Fairbanks et al., "The facts and myths of post-fire management: a case study of the Biscuit fire, southwest Oregon," Unpublished Report, World Wildlife Fund, Klamath-Siskiyou Program, Ashland, Ore, USA, 2006.

[11] R. L. Hutto, "Toward meaningful snag-management guidelines for postfire salvage logging in North American conifer forests," Conservation Biology, vol. 20, no. 4, pp. 984-993, 2006.

[12] J. Castro, C. D. Allen, M. Molina-Morales, S. Marañón-Jiménez, Á. Sánchez-Miranda, and R. Zamora, "Salvage logging versus the use of burnt wood as a nurse object to promote post-fire tree seedling establishment," Restoration Ecology, vol. 19, no. 4, pp. 537-544, 2011.

[13] R. L. Senft, M. B. Coughenour, D. W. Bailey, L. R. Rittenhouse, O. E. Sala, and D. M. Swift, "Large herbivore foraging and ecological hierarchies," BioScience, vol. 37, pp. 789-799, 1987.

[14] A. W. Illius, "Linking functional responses and foraging bahaviour to population dynamics," in Large Herbivore Ecology, Ecosystem Dynamics and Conservation, K. Danell, R. Bergstrom, P. Duncan, and J. Pastor, Eds., pp. 71-96, Cambridge University Press, Cambridge, UK, 2006.

[15] P. Acebes, J. Traba, J. E. Malo, R. Ovejero, and C. E. Borghi, "Density and habitat use at different spatial scales of a guanaco population (Lama guanicoe) in the Monte desert of Argentina," Mammalia, vol. 74, no. 1, pp. 57-62, 2010.

[16] N. T. Hobbs and I. J. Gordon, "How does landscape heterogeneity shape dynamics of large herbivore populations," in Dynamics of Large Herbivore Populations in Changing Environments: Towards Appropriate Models, N. Owen-Smith, Ed., pp. 141-164, Wiley-Blackwell, Chichester, UK, 2010.

[17] E. Baraza, R. Zamora, and J. A. Hódar, "Conditional outcomes in plant-herbivore interactions: neighbours matter," Oikos, vol. 113, no. 1, pp. 148-156, 2006.

[18] E. Baraza, R. Zamora, J. A. Hódar, and J. M. Gómez, "Plantherbivore interaction: beyond a binary vision," in Handbook of Functional Plant Ecology, F. I. Pugnaire and F. Valladares, Eds., pp. 481-514, Marcel Dekker, New York, NY, USA, 2nd edition, 2007.

[19] M. Hebblewhite and E. H. Merrill, "Trade-offs between predation risk and forage differ between migrant strategies in a migratory ungulate," Ecology, vol. 90, no. 12, pp. 3445-3454, 2009.

[20] M. A. Relva, C. L. Westerholm, and T. Kitzberger, "Effects of introduced ungulates on forest understory communities in northern Patagonia are modified by timing and severity of stand mortality," Plant Ecology, vol. 201, no. 1, pp. 11-22, 2009.

[21] T. M. Anderson, J. G. C. Hopcraft, S. Eby, M. Ritchie, J. B. Grace, and H. Olff, "Landscape-scale analyses suggest both nutrient and antipredator advantages to Serengeti herbivore hotspots," Ecology, vol. 91, no. 5, pp. 1519-1529, 2010.
[22] P. Savill, J. Evans, D. Auclair, and J. Falck, Plantation Silviculture in Europe, Oxford University Press, Oxford, UK, 1997.

[23] K. A. Dwire, S. E. Ryan, L. J. Shirley, D. Lytjen, N. Otting, and M. K. Dixon, "Influence of herbivory on regrowth of riparian shrubs following a wildland fire," Journal of the American Water Resources Association, vol. 42, no. 1, pp. 201-212, 2006.

[24] R. Gill, "The influence of large herbivores on tree recruitment and forest dynamics," in Large Herbivore Ecology, Ecosystem Dynamics and Conservation, K. Danell, R. Bergstrom, P. Duncan, and J. Pastor, Eds., pp. 170-202, Cambridge University Press, Cambridge, UK, 2006.

[25] J. R. Biggs, D. M. Vanleeuwen, J. L. Holechek, and R. Valdez, "Multi-scale analyses of habitat use by Elk following wildfire," Northwest Science, vol. 84, no. 1, pp. 20-32, 2010.

[26] M. J. Baeza and V. R. Vallejo, "Ecological mechanisms involved in dormancy breakage in Ulex parviflorus seeds," Plant Ecology, vol. 183, no. 2, pp. 191-205, 2006.

[27] M. Hebblewhite, R. H. Munro, and E. H. Merrill, "Trophic consequences of postfire logging in a wolf-ungulate system," Forest Ecology and Management, vol. 257, no. 3, pp. 1053-1062, 2009.

[28] C. Puerta-Piñero, A. Sánchez-Miranda, A. Leverkus, and J. Castro, "Management of burnt wood after fire affects postdispersal acorn predation," Forest Ecology and Management, vol. 260, no. 3, pp. 345-352, 2010.

[29] M. de Luis, J. Raventós, and J. C. González-Hidalgo, “Factors controlling seedling germination after fire in Mediterranean gorse shrublands. Implications for fire prescription," Journal of Environmental Management, vol. 76, no. 2, pp. 159-166, 2005.

[30] M. J. Baeza and J. Roy, "Germination of an obligate seeder (Ulex parviflorus) and consequences for wildfire management," Forest Ecology and Management, vol. 256, no. 4, pp. 685-693, 2008.

[31] A. B. Robles, P. Fernández, J. Ruiz-Mirazo, M. E. Ramos, C. B. Passera, and J. L. González-Rebollar, "Nine native leguminous shrub species of south-eastern Spain: allometric regression equations and nutritive values," in Sustainable Grassland Productivity, J. Lloveras, A. González-Rodríguez, O. VázquezYañez et al., Eds., vol. 11, pp. 309-311, Grasslands Science in Europe, EGF/SEEP, Madrid, Spain, 2006.

[32] B. M. Jáuregui, R. Celaya, U. García, and K. Osoro, "Vegetation dynamics in burnt heather-gorse shrublands under different grazing management with sheep and goats," Agroforestry Systems, vol. 70, no. 1, pp. 103-111, 2007.

[33] A. B. Leverkus, J. Castro, C. Puerta-Piñero, and J. M. ReyBenayas, "Suitability of the management of habitat complexity, acorn burial depth, and a chemical repellent for post-fire reforestation of oaks," Ecological Engineering, vol. 53, pp. 15-22, 2013.

[34] J. Castro, S. Marañón-Jiménez, A. Sánchez-Miranda, and J. Lorite, "Efecto del manejo de la madera quemada sobre la regeneración forestal post-incendio: desarrollo de técnicas blandas de restauración ecológica," in Proyectos de Investigación en Parques Nacionales: 2006-2009, L. Ramirez and B. Asensio, Eds., pp. 139-157, Organismo Autónomo de Parques Nacionales, Madrid, Spain, 2010.

[35] P. Cubas, "Ulex," in Flora Ibérica, S. Talavera, C. Aedo, S. Castroviejo et al., Eds., vol. 7(1), pp. 212-239, Real Jardín Botánico, CSIC, Madrid, Spain, 1999.

[36] S. L. King and B. D. Keeland, "Evaluation of reforestation in the Lower Mississippi River Alluvial Valley," Restoration Ecology, vol. 7, no. 4, pp. 348-359, 1999. 
[37] J. M. Gómez, J. A. Hódar, R. Zamora, J. Castro, and D. García, "Ungulate damage on Scots pines in Mediterranean environments: effects of association with shrubs," Canadian Journal of Botany, vol. 79, no. 6, pp. 739-746, 2001.

[38] D. García, R. Zamora, J. A. Hódar, J. M. Gómez, and J. Castro, "Yew (Taxus baccata L.) regeneration is facilitated by fleshyfruited shrubs in Mediterranean environments," Biological Conservation, vol. 95, no. 1, pp. 31-38, 2000.

[39] D. García and J. R. Obeso, "Facilitation by herbivore-mediated nurse plants in a threatened tree, Taxus baccata: local effects and landscape level consistency," Ecography, vol. 26, no. 6, pp. 739750, 2003.

[40] A. J. Hester, M. Bergman, G. R. Iason, and J. Moen, "Impacts of large herbivores on plant community structure and dynamics," in Large Herbivore Ecology, Ecosystem Dynamics and Conservation, K. Danell, R. Bergstrom, P. Duncan, and J. Pastor, Eds., pp. 97-141, Cambridge University Press, Cambridge, UK, 2006.

[41] W. J. Ripple and E. J. Larsen, "The role of postfire coarse woody debris in aspen regeneration," Western Journal of Applied Forestry, vol. 16, no. 2, pp. 61-64, 2001. 

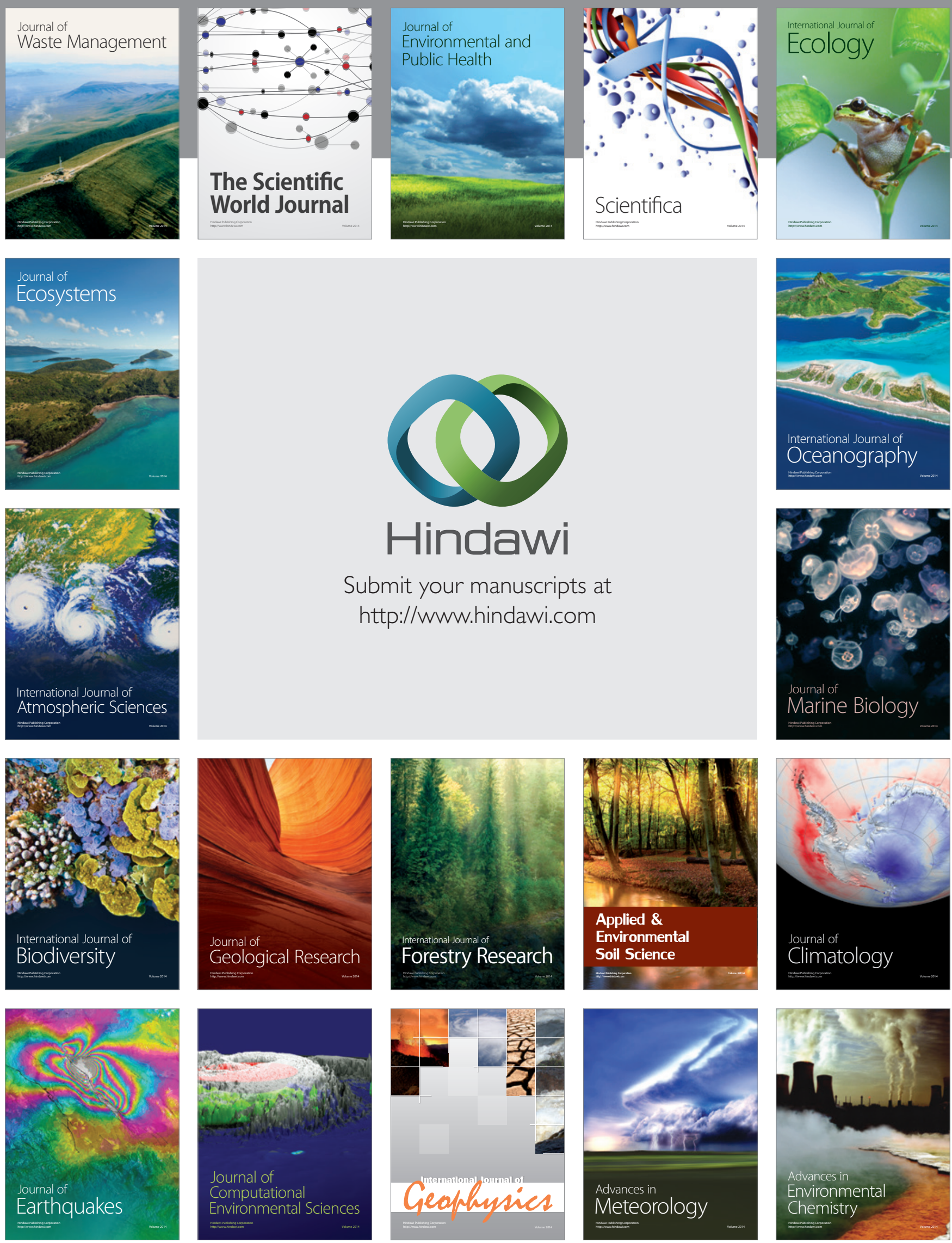